\title{
— PRILOG IZUČAVANJU PROBLEMA VREMENA I PROSTORA U KRUDIJEVIM PRIPOVETKAMA 0 SINDBADU
}

\author{
MARKO ČUDIĆ 1 \\ Univerzitet u Beogradu, \\ Filološki fakultet, \\ Beograd, Srbija
}

Veoma plodni klasik mađarske proze XX veka, Đula Krudi (Gyula Krúdy, 1878-1933), u mladosti pod vrlo snažnim uticajem anegdotske pripovedačke tradicije čijim se utemeljivačem u mađarskoj književnosti smatra Krudijev dugogodišnji spisateljski uzor, Kalman Miksat (Kálmán Mikszáth, 1847-1910), pronašao je svoj autentični pripovedački glas tek kada se oslobodio tog uticaja, tako što je postepeno uspeo da stvori jedan osetljiviji, liričniji prozni stil koji će kasnije postati Krudijev stilistički znak raspoznavanja. Krudi se u mađarskoj književnosti smatra utemeljivačem proze koja praktično nema fabulu, u kojoj se „ništa ne događa”. Krudijev prvi i najvažniji književni alter ego, moreplovac Sindbad, luta (peri) panonskim krajolikom, i, zalazeći u mala, idilična provincijska mesta nekadašnje Austrougarske monarhije, pokušava da rekonstruiše i ponovo proživi vlastitu prošlost, osećaj strasti i ljubav koju je nekada davno prema raznim ženama gajio. Autor ovog rada nastoji da pruži izvestan doprinos narativnom i poetičkom tretmanu vremena i prostora u Krudijevim pripovetkama o Sindbadu. Nostalgičnom evokacijom prošlosti (onakve kakva verovatno nikada nije ni bila, barem ne u obliku u kojem je u ovim pripovetkama opisana, prizvana), stvaranjem pripovedačke iluzije varošica „zamrznutih u vremenu”, Krudijev pripovedač kreira neobičnu i gotovo neprirodno veliku distancu između svoje sadašnjice i ne toliko daleke prošlosti koju nastoji da opiše. Prostorne distance koje njegov alter ego prelazi, mada geografski gotovo beznačajno male, u naratorovom prikazu poprimaju enormno velike, katkad i groteskne dimenzije. Tumači se, međutim, slažu oko toga da su ova putovanja suštinski temporalna i unutrašnja.

Ključne reči: nostalgija, evokacija prošlosti, asocijativna mašta, lirska proza.

1 Kontakt podaci (Email): marko.cudic@gmail.com 
Ni do danas nije do kraja utvrđeno koliko je tačno dela napisao neobično plodni mađarski pisac sa početka dvadesetog veka Đula Krudi (Krúdy Gyula, 1878-1933). Jedan od razloga za to možda leži u činjenici da je ozbiljnije tumačenje Krudijevog opusa u svoj njegovoj složenosti, zbog nekih poetičkih specifičnosti njegove proze, usledilo tek znatno kasnije, mnogo decenija posle piščeve smrti.

Nesumnjivo je da čak ni do tog naknadnog otkrivanja značaja njegovog dela ne bi nikada došlo da se Đula Krudi, to dete osiromašenih plemića iz grada Njiređhaza (Nyíregyháza) u severoistočnoj Mađarskoj, nije na vreme oslobodio onog, u tadašnjoj književnosti već pomalo zastarelog, manira anegdotičnosti koji je baštinio njegov veliki prethodnik i učitelj, jedan od najznačajnijih mađarskih prozaista XIX veka, Kalman Miksat (Mikszáth Kálmán, 1847-1910). Mnogo je razloga zbog kojih je Miksat izvršio tako snažan uticaj na Krudija. Jedan od njih možda se krije i u biografskoj činjenici da je Krudi pohađao gimnaziju - koju, inače, nikada nije završio jer se kao petnaestogodišnji dečak posvetio boemiji, noćnom životu, ženama i profesionalnom novinarstvu - u zabačenoj planinskoj varošici Podolin u današnjoj Slovačkoj, te da mu je, kao mladiću, Miksatov svet slovačkih i mađarskih seljaka iz severnih krajeva Ugarske (tzv. Paloca) mogao biti u jednom trenutku doživljajno blizak. No vremenom će Krudi shvatiti da mu ne odgovara toliko Miksatov nešto,robustniji", epsko-anegdotski stil pripovedanja prožet finim humorom i ironijom, pa će se sve više okretati jednom znatno osetliivijem, liričnijem proznom izrazu. Tim stilom Đula Krudi će prvi put autentično i snažno progovoriti u pripovetkama o svom prvom velikom alter egu, moreplovcu Sindbadu, koji će vremenom izrasti u modernog književnog putnika prvoga reda. Tu Krudijevu veliku stilističku transformaciju i iznenadno nalaženje autentičnog autorskog glasa, vojvođanski istoričar književnosti Imre Bori sažeo je u sledećoj konstataciji: „Objavljivanje prve pripovetke o Sindbadu (Sindbad moreplovac. Njegovo prvo putovanje) januara 1911. godine znači ujedno, po nepodeljenom mišljenju istraživača Krudijevog dela, i jednu od najvažnijih umetničkih prekretnica u piščevoj karijeri: ovom će pripovetkom dotadašnji »miksatovski« Krudi postati »modernim« piscem." (Bori 1978: 53).²

Ta novostečena poetička samostalnost i autentični pripovedački glas ogledaju se pre svega u specifičnom, modernom pripovedačkom odnosu prema vremenu. Poput drugih pripovedača sa početka stoleća, i Krudi će se, kako primećuje autor jedne od zapaženijih monografija o njemu, Bela Cere, već počev od svojih najranijih kratkih romana, "služiti nešto klasičnijom metodom rastakanja tradicionalnog linearnog vremenskog toka radnje, kada u sadašnjost utkiva prošlost, tako što povremeno prekida lanac pripovedanja, evocirajući, na posebnoj, izdvojenoj niti radnje, događaje iz nekog ranijeg perioda." (Czére 1987: 30). Ali, to je bio samo početak, i po takvom postupku Krudi se ni po čemu ne bi naročito izdvajao od čitave plejade svojih ispisnika. Ono što Krudijevu inovaciju na nivou pripovedačkog odnosa prema vremenu čini dubljom i suštinskijom, jeste, kako isti Krudijev monograf primećuje, jedan specifičan spisateljski metod koji se služi asocijativnom fantazijom ne bi li evocirao slike iz prošlosti, specifičan postupak pripovedačkog sećanja. Po tom elementu, i samo po tom, bilo bi osnova da se, kako tvrdi Bela Cere, uporede (ali samo kao vrlo daleki i slučajni spisateljski srodnici) Đula Krudi i Marsel Prust. (Czére 1987: 7-8). Mnogi istoričari književnosti (među kojima

2 Svi prevodi citata sa mađarskog jezika su moji - M. Č. 
prednjači Bori) nastojali su da dokažu kako ta, pomalo do opšteg mesta dovedena paralela, ne može biti utemeljena ni na pozitivističkim činjenicama (nema nikakvih naznaka da je Krudi čitao Marsela Prusta), niti na bilo kakvom tekstualnom paralelizmu ili oponašanju postupaka. Ali da je Bergsonovo učenje o vremenu, a naročito o distinkciji između objektivnog i subjektivnog vremena, makar i na posredan način delovalo i na Krudija, o tome već ne može biti mnogo spora. Jer ako, kako to primećuje Valter Benjamin, „Proustovo delo U potrazi za izgubljenim vremenom možemo smatrati pokušajem da se iskustvo, kako ga Bergson zamišlja, sintetički uspostavi u današnjim društvenim uslovima" (Benjamin 1974: 179), onda bi se moglo reći da su i traganja Krudijevih junaka (a naročito njegovog Sindbada) u velikoj meri rukovođena sličnom tendencijom. Ali na tome, na toj, suštinski istoj spoljašnjoj motivaciji, završava se gotovo svaka realna i koliko-toliko dokaziva paralela između Krudija i Prusta.

Drugi nivo problema, kada je odnos prema vremenu u pitanju, karakterističan je za Krudijevo pripovedanje. U tom konktekstu, naročito značajno mesto Bela Cere posvećuje specifičnom krudijevskom doživljaju tzv. zaustavljenog, zamrznutog vremena. Korene ovakvog poimanja vremena kod Krudija Cere pokušava da nađe u onome što je Danilo Kiš, tragom Sartra, nazvao "podmuklim delovanjem biografije”. (Kiš 2006: 224). Evo jednog nešto dužeg citata od Bele Cerea, kojim se nastoji pokazati veza između planinske varošice Podolin u kojoj je pisac proveo ključne godine svoje mladosti i ovog pripovedačkog traganja za umrtvljenim vremenom:

Podolin je bio jedna od onih trinaest varošica sepeškog kraja koje je kralj Žigmond (Sigismund) dao u zalog Poljskoj, da bi tek u XVIII veku, za vladavine Marije Terezije, ovi gradovi bili vraćeni pod mađarsku krunu. Tako je razvoj Podolina zaustavljen u vremenu, pa je ova varošica starodrevne atmosfere, zamrznuta u srednjem veku, izgledala kao nekakav časovnik bez brojeva, na kome se jedino klatno na satu staroga tornja vekovima klatilo između Poljske i Ugarske. Podolin je Krudiju pružio taj doživljaj zaustavljenog, u prošlosti zamrznutog vremena, i nije slučajno što će mesto radnje brojnih njegovih romana i pripovedaka vezanih za severne krajeve Mađarske, biti upravo Podolin. Doživljaj zaustavljenog vremena je za Krudijevu fantaziju značio to da se predeo u kome je vidljiv duh prošlosti, ta materija što lebdi između sadašnjosti i prošlosti, pošto se već i sama pretvorila u parče istorije, može mnogo lakše u osetljivoj pesničkoj svesti razdvojiti od realnosti - koja je teška kao olovo i često posve neupotrebljiva za imaginaciju - nego neko mesto lišeno te i takve patine davne ili ne toliko davne prošlosti. (Czére 1987: 20).

Međutim, poverovati da je Đula Krudi nekakav nostalgični i patetični „pisac prošlosti“ značilo bi upasti u zamku koju je, kako tvrdi Imre Bori, pisac sam postavio. Naprotiv, tvrdi ovaj istoričar književnosti,da kod njega nema jedne, poetički dosledno sprovedene, radikalne opozicije između stvarnosti onakve kakva je nekada bila (reč je, konkretno, o pripovetkama o Sindbadu, mada je to uočljivo i u velikom broju drugih Krudijevih dela), ili kakvom se zamišlja s jedne, i fizički i duhovno osiromašene „pustoši“ sadašnjice, koja elementarnom snagom pogađa Krudijeve junake, s druge strane, Krudi nikada ne bi postao tako velikim piscem i inovatorom. (Bori 1976: 67-69).Jer svaki veliki pisac nosi u sebi (pored ostalog) i neponovljivu sposobnost da umetnički uobliči atmosferu upravo svoje epohe. Bori, na drugom mestu, ide čak i dalje, pa tvrdi da, uprkos prividu misticizma, mi kod Krudija (a naročito upravo u pripovetkama o Sindbadu), u 
sećanjima njegovog junaka ne možemo naći ništa neobjašnjivo i mistično: „Možemo, doduše, osećati mistiku draži za sećanjem, pa ipak, Sindbadovi susreti sa realnošću nisu mistični. Pisac ne želi da obmanjuje čitaoca", kaže Bori. (Bori 1978: 58). U tom smislu, sa Borijem se slaže i Čila Utaši, koja, na tragu prvog i u pionirskom smislu vrlo prodornog tumačenja Krudijeve poetike iz pera njegovog savremenika Aladara Šepflina (Schöpflin Aladár, 1872-1950), suprotstavlja Sindbadovo „vreme bajke” sa i te kako konkretnom i vremenskim koordinatama određenom Sindbadovom ličnošću, čemu, tvrdi ova teoretičarka, treba još pridodati i konkretne fizičke opise mode, naročito kod žena, koji nose na sebi pečat jednog određenog vremena i određenog kulturološkog miljea iz vremena kada, u drugoj polovini XIX veka, u arhitekturi i umetnosti uopšte, vlada pravac poznat kao secesija. (Utasi 1997: 38-39).

Slično je situacija i sa inovacijom koju Krudi unosi u percepciju prostora. Ona bi se, u najkraćem, mogla odrediti kao tumačenje prostornih odnosa i mesta uslovljeno atmosferom, sećanjem na prohujale trenutke sreće, dalekim zvukom koji nestaje u ponorima prošlosti i sl. To će, kao što ćemo videti, svoj najsnažniji izraz dobiti upravo u pripovetkama o Sindbadu. To je ona vrsta poimanja prostora čiju je psihološku prirodu percepcije Moris Merlo-Ponti odredio na sledeći način: „Mi ne percipiramo gotovo nijedan objekt, kao što ne vidimo oči nekog poznatog lica već njegov pogled i njegov izraz. Ima tu jedan latentan smisao, razliven krajolik ili grad, koji prepoznajemo u jednoj specifičnoj evidenciji, ne osjećajući potrebu da ga definišemo." (Merleau-Ponty 1978: 295). Prostorne distance, baš kao i u slučajevima vremenskih distanci (fingirano vreme bajke kod Sindbada), kod Krudija se, kao što ćemo takođe uskoro videti, često preuveličavaju do mitskih, na momente i komično grotesknih i neverovatnih razmera.

Specifični književni alter ego je, pak, druga važna novina koju Đula Krudi unosi u mađarsku prozu. Pisac biografske monografije o Krudiju, Ede Sabo, citirajući pouzdane podatke kojima raspolaže Bela Katona (Katona Béla), naglašava značaj čarobnog sveta bajki iz Hiljaduijednenoći za mladog Krudija: „Najdublji uticaj na njegovo formiranje kao čoveka i pisca verovatno je izvršila Šeherezada. Toliko ga je opčinio taj svet istočnjačkih bajki, toliko se uživeo u ulogu junakâ tih fantastičnih pustolovina, da je od tada počeo nazivati sebe Sindbadom." (Szabó 1970: 40). Poistovećivanje empirijskog Krudija sa Sindbadom nije bila nikakva tajna. Nekrolozi savremenika, objavljeni u nizu dnevnih listova, u kojima ga više puta nazivaju Sindbadom, rečito svedoče o tome. (Tóbiás 2003: 281-308). 0 snažnom uticaju ovog junaka iz Šeherezade na mladog pisca govori i Bela Cere: „I njegovog dvojnika, koji plovi vodama sećanja, večito ka uvek novim lukama tera žeđ za pustolovinama iz Hiljadu i jedne noći". (Czére 1987: 23).

Ta površinska, biografska mladalačka identifikacija sa junakom iz lektire nije i ne može, međutim, biti dovoljno jak argument kojim bi se mogla objasniti ovakva, gotovo opsesivna privrženost takvom alter egu i njegovo konstituisanje u jednoj višoj, modernijoj književnoj sferi. Imre Bori smatra da je:

[...] [S]vrsishodnije da se potreba za alter egom, oličenim u Sindbadu, tumači kao stvaralački problem, i to problem koji je u tesnoj vezi sa "odsustvom radnje", tako karakterističnom za Krudija, koje u prvoj deceniji dvadesetog veka ni anegdota više nije mogla zameniti. Reč je o spoznaji koju bismo nazvali nemogućnošću direktnog predstavljanja, a koju je od svih mađarskih savremenika izgleda 
baš Krudi najintenzivnije proživeo, istovremeno sa velikim svetskim piscima, književnim inovatorima njegove epohe. U pripovetkama o Sindbadu prvi put nailazimo na očigledan trag želje za zadovoljenjem zahteva da pisac ne treba da opiše ono što se dogodilo, nego treba da piše o tome da se ništa ne dešava, te da sve zahteve devetnaestovekovne epike valja preispitati. Epski događaj će, dakle, u Krudijevoj umetnosti postati zaista senzacija duše, koja više nije u stanju da prikaže sistem spoljašnjeg sveta u svoj njegovoj celovitosti, već samo u delovima, čime će piščeva svest dobiti znatno veći značaj nego deceniju-dve pre toga: ona pruža sigurniji oslonac od stvarnosti sveta koja nestaje, i delimično ili u potpunosti stupa na njeno mesto. (Bori 1976: 71).

U samom izboru Sindbada kao alter ega krije se, prema Borijevom mišljenju, još jedna izuzetno važna tendencija epohe. Nije, naime, svejedno koga pisci biraju za junake svojih knjiga, a još je manje svejedno koga biraju za svog stalnog pratioca, za svoj alter ego. U tom kontekstu ni izbor određenih likova iz starije književnosti ili drevne mitologije nije, niti može biti ni slučajan niti nasumičan. Tako je, po Borijevom mišljenju, izbor Sindbada izraz vapaja epohe za čvrstim, večnim uzorom, utemeljenom u bezvremenosti mita:

Sam izbor imena, međutim, već prevazilazi i piščeva objašnjenja, i u svom dubljem značenju ukazuje na problematičan karakter epskog prikazivanja kao takvog: tu se pojavljuje isti onaj spisateljski momenat koje će upravo negde u to vreme u svetskoj književnosti inaugurisati Džojs time što će za glavnog lika svog romana postaviti Uliksa koji je, baš kao i Sindbad, „moreplovac“. Krudiju je takođe bila potrebna večni, bezvremeni primer, u čemu se nazire potreba za mitologijom koju je ta epoha baštinila, a iz te činjenice stiče se uvid i u najkomplikovanije slojeve problema moderne proze: primena gotove mitološke sheme života predstavljala je jednu od mogućih formi da pisac uspostavi nekakav red, pomoću nje mogla se pronaći ta uzaludno tražena „priča”. (Bori 1976: 72).

Krudijev kasni, devetnaestovekovni Sindbad-moreplovac, uprkos povremenim pripovedačevim aluzijama da je napunio "trista godina", da voli da šeta stambolskim bazarima i tome slično - a takvi umeci povremeno deluju čak i groteskno i smešno u poređenju sa ostatkom teksta, i kao da namerno toliko odstupaju od srednjoevropskog, konkretno od mađarskog koordinatnog sistema koji dominira ovim pripovetkama - u punoj je meri dete svoje epohe i svoje otadžbine. Imre Bori tvrdi da je Krudi, koji svog Sindbada prikazuje u večitom sukobu sadašnjosti i prošlosti, u njemu „otkrio čoveka epohe secesije u kojem se izražava dijalektika sadašnjosti i prošlosti." (Bori 1978: 6263). Krudijev Sindbad je neka vrsta fanatika prošlosti. Pripovedač, kroz opise varošica u kojima je „vreme stalo", kroz prikaz već odavno nepostojećih ili nepotrebnih predmeta, želi da izrazi, kako kaže Bori, kontinuitetjednog autentično mađarskog sveta mađarskih provincijskih varošica „zamrznutih“ u vremenu. (Bori 1976: 87).

Savremeni američki filozof arapskog porekla Hakim Bej kaže da je jedna od čari (onih pravih, originalnih, arapskih) priča o Sindbadu to što nas one nekako uvek „vraćaju kući“ (Bej govori iz perspektive arapskog čitaoca, naravno), što Sindbad ima neku moć, neku auru kojom sve stvari koje dotakne „odomaći“" „Čitajući priče o Sidbadu moreplovcu (iz Hiljaduijedne noći) pred nama se iscrtava jedan svet u kojem je čaki terra 
incognita - uprkos svoj svojoj neobičnosti, nesvakidašnjosti - nekako poznata, nekako muslimanska." (Bey 1996). Ako je to tačno, ako arapski čitalac predele kojima Sindbad moreplovac putuje doživljava - uprkos drastičnim razlikama u spoljašnjem izgledu kao svoje (u prvom redu zbog celokupne atmosfere i same Sindbadove ličnosti), onda je Krudijev mađarski Sindbad u tolikoj meri autentično mađarski da, gde god pošao, svi predeli kojima ide, izgledaju nepopravljivo austrougarski, i, u okviru toga, mađarski. Zajedničko arapskom Sindbadu i ovom Krudijevom, mađarskom, jeste pre svega to što su obojica na neki čudan način hodočasnici.

Ali, ko je zapravo taj famozni Krudijev Sindbad, kako ga to Krudijev pripovedač opisuje? Najbolje bi možda bilo poći od velikog broja epiteta koji mu se pridaju, da bi se shvatilo u kolikoj meri je putovanje ono što ga suštinski određuje. Evo samo nekih od mnogobrojnih pripovedačevih određenja koji Sindbada definišu, između ostalog, i kao velikog putnika: „To je nekada davno bio Sindbad, neumorni putnik, prijatelj žena, kavaljer gospođa što sanjaju u malovaroškim kućama, poslednja ovozemaljska misao devica što ulaze u samostan, nada ostarelih dama..." (Krúdy 1975: 189). Na drugim mestima, pripovedač ga opisuje kao „drevnog pustolova”(Krúdy 1975: 256), „slavnog pustolova"(Krúdy 1975: 258), , neobičnog pustolova avanturističkog rečnika, remetioca damskog mira"(Krúdy 1975: 300). U pripoveci Iszkiri (Tutanj) u kojoj Krudijev junak beži od jedne podivljale dame, epitet koji Sindbad nosi je "heroj mnogih ljubavnih ludosti". (Krúdy 1975: 372). U pripoveci A szerelem lexikona (Leksikon ljubavi), pak, već u prvoj rečenici, uz ime Sindbad, stoji apozicija "ta pustolovna umetnička individua”. (Krúdy 1975: 384). Ostali njegovi varijabilni, pa ipak, kad je motiv pustolovnosti i putničke egzistencije u pitanju, itekako konstantni atributi, uključuju još i sledeća, manje-više slična određenja: „stari putnik" (Krúdy 1975: 405), „milostivi gospodin skitnica Sindbad, Ibi-ubi" (Krúdy 1975: 490), "divlji veslač" (Krúdy 1975: 497), „gospodin koji se smuca nezakonitim putevima" (Krúdy 1975: 576). ${ }^{3}$

Ovo more Sindbadovih određenja koji u prvi plan nedvosmisleno guraju pustolovno-putničko-tragalačku komponentu Krudijevog najvažnijeg junakai alter ega, samo na trenutke biva prekinuto sporadičnim Sindbadovim atributima drugačije vrste, kao kada se, recimo, u pripoveci Az üveglopó (Kradljivac stakla) Sindbad, koji odjednom, iznebuha, izusti psovku, (pomalo ironično) opisuje kao „hodočasnik primernog životnog stila" (Krúdy 1975: 473). Ili, kada se umesto te svetiteljsko-hodočasničke aure (ironično prenaglašene), na drugom mestu ovog gotovo nepreglednog mora Krudijevih pripovedaka o njegovom omiljenom morepolovcu, istakne Sindbadov pripovedački genij, onda on postaje „pripovedač starostavni“. (Krúdy 1975: 559). Treći takav primer bio bi kada se ističe njegova dokonost, pa se on određuje kao "dokoni gospodin". (Krúdy 1975: 576). A ima i slučajeva starinskih, gotovo baroknih metapripovedačkih određenja:

3 Kad se svim ovim pripovedačevim (Krudijevim) atributima kojima on određuje svog Sindbada, doda još jedan, koji je formulisao jedan od najtemeljnijih tumača Krudijevog opusa, Jožef Sauder (Szauder József), koji Krudijevog alter ega Sindbada određuje, sasvim biografski, kao „pustolova koji se otgrnuo od (svog) vladajućeg staleža" (citat naveden prema Szabó 1970: 119) - jer Krudi je zaista bio plemićkog porekla, ali iz osiromašene porodice - jasno je koliko se i u samom sekundarnom diskursu o Krudijevom Sindbadu, pa i u diskursu o onome koji je tog Sindbada izmaštao i umetnički uobličio, uvrežilo mišljenje o Sindbadu-putniku i Sindbadu-pustolovu posebne vrste. 
„Sindbad, ponizni sluga ovoga romana“.(Krúdy 1975: 687). Pa ipak, sva ova, ne toliko malobrojna statička „intermeca" u kojima nam se čini da se pripovedač „odmara" od mnogobrojnih dinamičkih atributa kojima određuje svoga junaka, samo potvrđuju njegovu suštinsku putničku egzistenciju, bez koje se on praktično ni ne može zamisliti.

Ali, kakva su ta putovanja Krudijevog Sindbada, da li su ona baš uvek striktno prostorna i konkretna? Vrlo često ona to jesu (ili su tako prikazana), ali to nije baš uvek slučaj. Na nivou praćenja tradicije (tj. kvazi-intertekstualne analogije sa pravim Sindbadom, onim iz Hiljadu $i$ jedne noći) može se govoriti samo o metaforičkim putovanjima, jer, zapravo, jedini Sindbadov atribut od gore pobrojanih koji ukazuje na njegovo putovanje morem jeste „divlji veslač". Naime, odmah u prvom od dva Krudijeva romana o Sindbadu, u Francuskom zamku, mi već na samom početku saznajemo da je reč o imaginarnoj plovidbi koju junak drži pod punom (mentalnom) kontrolom:

Jedrenjak iz mašte, na kojem je dosad oplovio već toliko velikih voda i pristao u toliko lepih luka, uvek bi se upućivao samo u onom smeru u kojem bi Sindbad usmerio kormilo. Putovao je kod žena i muškaraca koje je voleo; jezdio je kroz predele u kojima gostionice kao da su sve do jedne bile nazvane po kralju Džordžu, kao u engleskim romanima, i gde su po snegom prekrivenim poljima čak i tragovi zečeva i lisica gospodinu Sindbadu bili dobro poznati. Prozori pod kojima bi se šetao, već su odavno bili otvoreni kada bi on tiho pokucao na njih, i stara služavka bi ga, sakrivši svetiljku pod kecelju, propratila kroz nepoznata dvorišta i uvela u nepoznate kuće. Tako je živeo Sindbad u svojim romanima. (Krúdy 1975: 631).

Ali, vratimo se pripovetkama o Sindbadu, koje, pomenuli smo to već, u određenom smislu mogu da se čitaju i kao romani. U tim pričama Sindbad putuje, razume se, i u većini slučajeva ta putovanja predstavljaju realna putovanja kopnom, u kočijama, postojećim geografskim koordinatama (istina, često su kilometraže i cifre preuveličane, ali to može biti i deo Krudijevog ironičnog pripovedačkog stava). Putujući tako, on se, kako primećuje Bela Cere, faktički obreo u svim krajevima Austrougarske Monarhije (Czére 1987: 61), izazivajući, naročito kod mađarskih čitalaca, snažan utisak da su svi ti krajevi nekako domaći, nekako mađarski. ${ }^{4}$ Sav Krudijev Sindbad kao da je uronjen u jedan ne tako davno prošli svet Austrougarske, i gotovo sve realije sa kojima se on na svojim putovanjima susreće su (bile) postojeće i proverljive. Povremeni nerealni, izmaštani umeci o njegovim plovidbama, o hiljadama morskih milja koje je prešao, 0 sirijskim trgovcima sa kojima se kartao, o stambolskim bazarima po kojima je tumarao, osećaju se kao namerno umetnuto strano telo u tekstu čiji je koordinatni sistem Srednja Evropa, tačnije jedna osobeno nostalgična slika Mađarske iz druge polovine XIX veka. Kao da je jedini cilj tih namerno umetnutih, i u sam kontekst pripovedaka o Sindbadu vrlo teško ukalupljivih reminiscencija na Šeherezadu,zapravo samo deo spoljašnjeg, moglo bi se čak reći i vantekstualnog okvira, obaveznog dekora priče, koji nas tek povremeno obaveštava o svom dalekom prototekstu.

4 Upor. u ovom radu već iznetu tezu savremenog filozofa Hakima Beja da Sindbad (onaj pravi, originalni) čini da se svi krajevi kojima krstari, zahvaljujući njegovoj auri i pripovedačevom umeću, osećaju kao domaći, kao arapski i muslimanski. 
Šta, najzad, Krudijevog Sindbada goni na put, koji porivi, kakav unutrašnji nemir, kakve želje? Kao što se iz velike većine Krudijevih pripovedaka o Sindbadu vidi, to je sredovečni gospodin, natprosečno visok, krupan i markantan, koji putuje da bi potražio i ponovo proživeo emocije prema ženama u koje je nekada, kao mladić, bio zaljubljen. Pripovedač se služi raznim trikovima kako bi inicirao Sindbadova putovanja. U pripoveci koja pripada značajnom ciklusu Szindbád utazásai (Sindbadova putovanja), pod naslovom Szindbád második útja (Sindbadovo drugo putovanje) pripovedač prilično eksplicitno izlaže prirodu tog putovanja svoga junaka u zrelim godinama:

Tako je prolazio život moreplovca Sindbada, sve dok najzad nije stigao u jedno razdoblje u kojem ga više ni sadašnjost ni budućnost nisu podsticale na razmišljanje i sanjarenje, već je na njihovo mesto došla prošlost, njegova davno prohujala mladost. I kao lađar koji je oplovio sva daleka mora i ne nalazi više nepoznatih zemalja, pa razapne jedra i krene nazad u svoju domovinu - tako je i Sindbad pošao da traži svoje uspomene iz mladosti. Kao da je još jednom poželeo da započne roman svoga života... Kao da traži nove i nepoznate osećaje...(Krúdy 1975: 38). ${ }^{5}$

Sada, u zrelom dobu, punom uspomena, nesanice i griže savesti zbog protraćenih ljubavi i svojeručno uništenih života mladih žena, Sindbadu podsticaj za putovanje ne daje više grozničava želja za otkrićima, za saznanjima, za, takoreći, primarnim doživljajima. Reč je o nečem sasvim drugom, prefinjenom i sekundarnom, o nečem što bi se u krajnjoj liniji najbolje moglo definisati kao svojevrstan, ne čak ni toliko duševnoosećajni, koliko jedan umetničko-estetski poriv. Specifično traganje za otkrivanjem umetnosti jedne nove vrste osećanja, izazvanih starim, primarnim i strastvenim emocijama, jeste ono što Krudijevog "moreplovca” čini toliko specifičnim, i to ne samo u mađarskoj književnosti. Imre Bori je u pravu kada primećuje da je Sindbadovo putovanje, uprkos prostornom izmeštanju, zapravo pre svega putovanje u vremenu. (Bori 1976: 74). Pri tom, Bori primećuje još nešto veoma važno, a to je činjenica da se Sindbadove uspomene ne sastoje od događaja (Bori 1976: 80) ${ }^{6}$ - one se sastoje od osećanja, od pogleda, od minijaturnih treptaja duše, od čulnih efemerida. No, svi ovi detalji iz samo jedne jedine pripovetke još nikako ne bi mogli biti dovoljni da ove Sindbadove potrage dobiju onu umetničku komponentu o kojoj je maločas bilo reči. Da bi ta umetnička komponenta Sindbadove specifične potrage mogla biti opipljivija, potrebno je da se, makar samo i u naznakama, pojavi nekakav suštinski sistemski karakter te potrage, koji bi se provlačio manje-više kroz ceo ciklus ovih pripovedaka. Taj programski umetnički karakter Sindbadove potrage Imre Bori nalazi upravo u gorepomenutoj dominaciji duševnih senzacija kao cilja potrage. Bori u tom kontekstu

5 Ede Sabo, pomalo uprošteno, kaže da su mnogi Krudijevi ključni likovi „nesrećni brodolomnici života”. (Szabó 1970: 6).

6 Na drugom, pak, mestu, Bori kaže, povodom tog flagrantnog nedostatka „događaja” - jedne tendencije baš i ne previše uobičajene u mađarskoj prozi toga vremena - da jedna od najvećih proznopoetičkih inovacija Krudijevog ciklusa pripovedaka o Sindbadu jeste upravo u tome što „, priče o Sindbadu sve vreme govore 0 tome da priče nema". (Bori 1978: 58). 
govori o specifičnom Sindbadovom „pesničkom projektu“ čiji je cilj vrlo osoben - to je, kako ističe ovaj istoričar književnosti, „potraga za novim i nepoznatim duševnim senzacijama." (Bori 1978: 61- 62). Tas na zamišljenoj „vagi motiva“ koji će prevagnuti u korist ovih drugih, duševno-čulnih senzacija nasuprot predmetnim - $\mathrm{i}$ to u tolikoj meri da će čak i kod prividno tako "nesistematičnog" pisca kao što je Krudi, dobiti karakter sistema i jednog umetničkog, pesničkog programa prvog reda - nalazi se u (empirijski) razočaravajućoj činjenici fabule, na koju takođe podseća Bori, da Sindbad na svojim (prostornim) putovanjima nalazi samo mrvice nekadašnje (tobož) bogate stvarnosti. (Bori 1978: 57).

\section{LITERATURA}

Benjamin, W. 1974. Eseji. Preveo Milan Tabaković. Beograd: Nolit.

Bey, H. 1996. „Az utazás művészete. Szufi utazók" [„Umetnost putovanja. Sufijski putnici", mađarski prevod Bejevog teksta]. Magyar Lettre Internationale, 23, zima 1996. Dostupno na: http://epa.oszk.hu/00000/00012/0007/09bey.htm Poslednji put pristupljeno 11. septembra 2016. godine.

Bori I. 1976. Fridolin és testvérei [Fridolin i njegova braća]. Novi Sad: Forum Könyvkiadó. Bori I. 1978. Krúdy Gyula. Novi Sad: Forum Könyvkiadó.

Czére B. 1987. Krúdy Gyula. Budapest: Gondolat Kiadó.

Kiš, D. 2006. Homo poeticus. Priredila Mirjana Miočinović. Beograd: Prosveta.

Krúdy Gy. 1975. Szindbád (drugo izdanje). Priredio Kozocsa S. Budapest: Magyar Helikon.

Merleau-Ponty, M. 1978. Fenomenologija percepcije. Preveo s francuskog dr Anđelko Habazin. Sarajevo: IP "Veselin Masleša".

Szabó E. 1970. Krúdy Gyula alkotásai és vallomásai tükrében [Đula Krudi u ogledalu svojih dela i izjava]. Budapest: Szépirodalmi Könyvkiadó.

Tóbiás Á. (prir.) 2003. Krúdy világa [Krudijev svet]. Budapest: Osiris Kiadó.

Utasi Cs. 1997. Krúdy Gyula elbeszéléskötetei a tízes években [Ciklusi pripovedaka Đule Krudija desetih godina dvadesetog veka]. Neobjavljeni magistarski rad. Novi Sad: Biblioteka katedre za hungarologiju Filozofskog fakulteta.

\section{SUMMARY}

\section{A CONTRIBUTION TO THE STUDY OF TIME AND SPACE IN THE SHORT STORIES OF GYULA KRÚDY ABOUT SINBAD}

A very prolific Hungarian writer of his time, GyulaKrúdy (1878-1933), in his young years strongly influenced by the anecdotal tradition of his long-term idol Kálmán Mikszáth (1847-1910), found his authentic narrative voice by breaking up with this tradition and creating a more sensitive, lyrical prose style. He created a modern prose in which seemingly "nothing happens". Krúdy's first and most important alter ego, Sinbad the Sailor, wanders across the landscape of small Austro-Hungarian idyllic towns and villages, trying to reconstruct and re-live his own past, the feelings of passion and 
love he once felt for various women. This paper aims to contribute to the narrative and poetical treatment of time and space in Krúdy's short stories about Sinbad. Through the nostalgic evocations of the past (which probably never really existed as described in this stories), through the illusion of small towns "frozen in the past", Krúdy's narrator creates an unusually and almost unnaturally big distance between his own time and the not so distant past he aims to describe. The distances in space, which his alter ego covers, though geographically relatively small ones, in the narrator's portrayal get enormous, sometimes even grotesque dimensions. Scholars do agree, however, that these journeys tend to be temporal and inner ones.

KEYWORDS: nostalgia, evocation of the past, associative fantasy, lyrical prose.

(Originalni naučni rad primljen 8.6.2017; ispravljen 31.10.2017; prihvaćen 31.10.2017) 